\title{
RNAi Induced Wing Modification in Leon Mutant Drosophila Females: Exploring the Tissue Specificity and Physiological Interference
}

Sandeep Satapathy ${ }^{1}$ and Cheng Ting Chien ${ }^{2}$

${ }^{1}$ Department of Biological Sciences, Indian Institute of Science Education and Research, Bhopal, India

${ }^{2}$ Department of Neurosciences, Institute of Molecular Biology (IMB), Academia Sinica, Taiwan, R.O.C, Taiwan

\begin{abstract}
The precision of growth of an animal is meticulously regulated by extrinsic and intrinsic factors, with focus on maintenance of organismal homeostasis. The clue to change in physiology or metabolism of an organism, at times, can be derived from the changes in phenotypes. In the Drosophila melanogaster model system, GAL 4-overexpressed RNAi driver males (Mini-White Marker), targeted against specific genes, when crossed with Leon mutant (19-2/TM6B) females, yield progeny of different wing types. Different RNAi lines expressing the phenotypes in a gradient of sodden, mid to normal, explains the varying severity of the wing phenotypes. The comparison of flies co-expressed RNAi and Leon mutant with wild type or Leon mutant females, show changes in wing phenotype; in terms of wing venation, anterior cortical vein (acv) position, posterior cortical vein (pcv) position, bristles on the wing margins and the intersegmental distance. There is a distinct evidence of both rescue and deterioration phenotype observed at various levels, with the varying levels of RNAi expression in sodden, mid and normal type. A correlational study of these modified wing phenotypes to the physiological and metabolic functionalities, reveals the expression of most of these genes targeted by RNAi, mainly in the brain, heart, thoracic-abdominal ganglion, salivary gland, ovary and testis. Therefore, it can be hypothesized that the Leon mutant can be correlated with the RNAi.
\end{abstract}

Keywords: Leon mutant; Hedgehog; Wing imaginal disc; Crossveins; Segmental distance; RNAi; Gal4 ms-1096

\section{Introduction}

In Drosophila melanogaster, the finest genetic toolbox and the feasibility of use of balancer chromosomes, makes it viable for use as an efficient model system for study of genetic and molecular mechanisms associated with development. The central importance of body size and shape in evolutionary biology has been further established by distinct external wing phenotypes. The patterning of wing veins, bristles and the shape of the wing, eventually attempt to decipher the molecular and chemical intricacies of sequential development of organism. Leon, the protein of interest is involved in dendritic aborization shortening in neurons and also higher puncta formation, enabling in faster short-range neuron impulse transmission. The wing, being one of the distinctly viewed phenotype, is an ectodermal structure with well-defined compartmentalization of the wing contents and portions into two distinct groups of boundary classifications; one being anterior-posterior and the other being dorsal-ventral [1-4]. The dorsal and ventral epithelial sheets are considered to superimpose on each other, to form what we see as an ectodermal wing blade in its mature form. The mature wing blade is an outcome of fate decision of different group of cells present in the larval imaginal disc. The final outcome however is seen at the end of 4-5 days after pupariation (AP). Several researches have proved the effect of natural variation on wing development, and also the studied the effect of wing patterning in several Drosophila mutant lines. Although the aerodynamics associated with the wing blades in insects and smaller organisms stands out to be clearly understood, but the consequential effect of variation on wing morphology is still under research. The precise consensus of these environmental factors and the reception at the organismal level has been consensused by five basic intra-cellular signaling pathways; Hedgehog Signaling (Hh), Bone Morphogenetic Protein (BMP), Epidermal growth factor receptor (Efgr), Wnt and Notch Signaling [5]. Optimizing selection on wing shape in natural populations is a very distinct pattern [6]. The heritability (in higher degrees), specifically in D. mediopunctata species, has also proved genetic flow of information for this optimizing selection criteria [7]. Vein cells and intervein cells (found between veins) are the two basic groups of cells in an adult wing blade determining the venation pattern, with the former being densely packed with higher cuticular pigments than the later one. It is known that the vein cells are the only living cells in a mature wing blade because of the loss of the intervein cells shorty after pupariation (AP).The most common nomenclature of wing blade includes; five longitudinal veins (LVs) ranging from L1- L5 with proximoditsal directionality. Two small rudimentary veins, L0 and L6 are found at the proximal end of wing blade. Three Crossveins (CVs) are anterior crossvein (acv) (L3-L4), posterior crossvein (pcv) (L4-L5) and humeral cross vein (L0 and wing margin) $[5,8]$. The dorsal and ventral differentiation of wings arise out of the differential protrusion of veins on either side of the wing blade w.r.t each other (Figure 1).

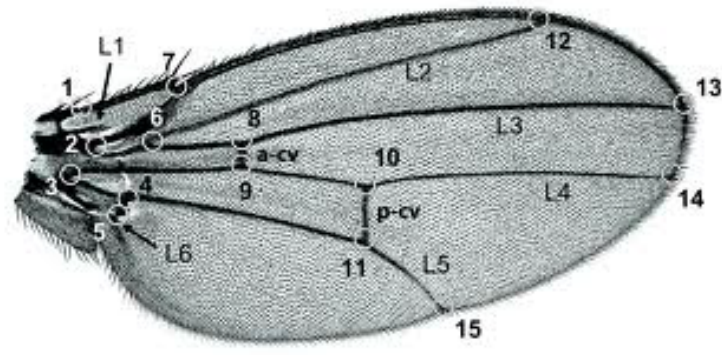

Figure 1: The mature Drosophila wing blade with vein classification

*Corresponding author: Sandeep Satapathy, Department of Biological Sciences Indian Institute of Science Education and Research, Bhopal, India, Tel: 917898664419; E-mail: sandeeps@iiserb.ac.in

Received September 03, 2013; Accepted September 13, 2013; Published September 20, 2013

Citation: Satapathy S, Chien CT (2013) RNAi Induced Wing Modification in Leon Mutant Drosophila Females: Exploring the Tissue Specificity and Physiological Interference. Gene Technology 2: 104. doi: 10.4172/2329-6682.1000104

Copyright: (c) 2013 Satapathy S, et al. This is an open-access article distributed under the terms of the Creative Commons Attribution License, which permits unrestricted use, distribution, and reproduction in any medium, provided the original author and source are credited. 
Evolutionary basis of wing vein morphology clearly suggests the possibility of existence of additional veins in primitive wing or the deletion loss of veins w.r.t what existed earlier $[9,10]$.

\section{Wing development}

During embryonic development, 20-30 cells form a cluster, which invaginates from embryonic epithelium with still being adhered to the base with thin stalks. This is the earlier layout of wing development from the wing derived imaginal disc. The differentiation of the initial cluster of cells to a later folded disc epithelium (by the late third instar), is what actually forms the wing blades, hinges, and even the thorax of the fly [5] (initial stages of pupariation, there is an amalgamation of basal and dorsal wing epithelia and the longitudinal proveins forming gap). In contrary to the LV provein pattern in the developmental phase $\mathrm{AP}$, the mature wing shows a narrower vein with fusion of L3 and L4 at the proximal end, forming acv. However, the important question underlying this nomenclature of cells what decides the cell's fate, i.e. either to be a vein cell or an intervein cell, and the time of onset and completion of this process of differentiation. This distinctive process actually starts in the late pupariation stage and continues till 4-5 days AP. This decision of cell after is not resultant of invasive or migratory cells during imaginal disc development [11-13]. The five basic intracellular signaling pathways and associated novel components play a pioneer role in positioning of veins in wing blade. These signaling show a predominant wing localized effect. The signaling guided wing venation pattern is classified as: Hedgehog (L3-L4), BMP (L2-L3) (L4-L5), Efgr (Provein and Intervein development), Wnt and Notch signaling (L1-L2; L4-L5). The chemical morphogens that involves, the initial LV proveins being broader gets modified consequently, and thus gets refined to the normal narrow veins in the adult wing blade. The LV proveins of the dorsal and ventral side are formed separately on the wing imaginal disc, but in a later time of development, these get aligned to form the gap between the veins on the dorsal and ventral surfaces in a mature wing blade [7]. The developmental signaling of LVs and CVs are roughly same with exception being the precise positioning along the anterior-posterior part and proximo-distal part (Figure 2).

The GAL4 or Upstream Activator Sequence (UAS) is an exquisite genetic tool in GAL-mediated overexpression system for Drosophila for targeted gene expression. The use of GAL overexpression has been most commonly for study of mis-expression. However the stereotype has been added with new dimensions for study of gene of interest via enhancers, cellular autonomy of a gene product analysis and analysis of loss of function phenotypes through targeted use of RNAi and dominant negative constructs [12,14]. ms-1096 GAL4 is a tissue specific GAL4 protein that overexpresses the target protein, and thus helps in studying the protein functionalities. The use of GAL4 driven RNAi flies has shown a temperature dependence mating efficiency with the maturation cycle time period variation. The most ambient temperature for a GAL driven fly is considered to be $28^{\circ} \mathrm{C}$, with minimal activity being noted at $16^{\circ} \mathrm{C}$. Post translational gene silencing (PTGS) or RNAi (interfering RNA), using siRNA (small interfering RNA) or miRNA (micro RNA), is best suited for studying the function of a particular gene by either knocking down or knocking out a particular gene coding for a specific product. The RNAi microinjected flies targeted against specific genes, in their downstream, manifest their effect in terms of the wing phenotype changes. The presence of the balancers is confirmed by a dominant mutation called Mini White, which coats for red eye color of the fly. Cyo balancers show a distinct curved wing and TM6B causes short-bodied flies with increased number of bristles on the shoulder part. Correlating modified wing phenotypes to the physiological and metabolic functionalities reveals the expression of most of these genes targeted by RNAi, mainly in the brain, heart, thoracic-abdominal ganglion, salivary gland, ovary and testis. Therefore, the clue to change in physiology or metabolism of an organism, at times can be derived from the changes in phenotypes. Even Drosophila, may retain some of the information, as the ectopic veins formed after genetic manipulations, can in some cases mimic aspects of the homologs pattern $[6,14,15-18]$.

\section{Materials and Methods}

\section{Drosophila stocks}

The stocks used for analysis are collected from three stock centers; Vienna Drosophila RNAi center (VDRC), Bloomington RNAi Drosophila stock center (BL) and NIG-Fly. The stocks are described at http://flybase.org unless indicated otherwise. The stocks were also differentially overexpressed with RNAi and the Severity of over expression was arranged chronologically [18-21].
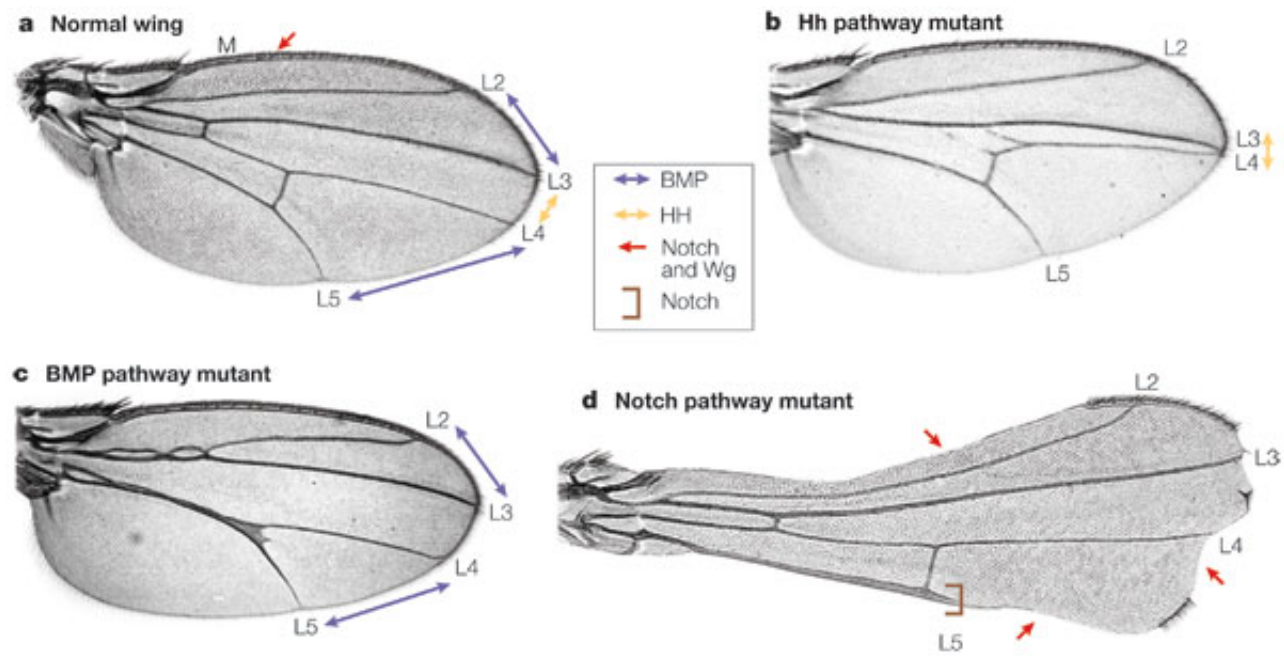

Nature Reviews | Genetics

Figure 2: Intra-cellular signaling pathways and the positioning of wing veins [18] 


\section{Crossing of flies}

The Leon mutant (19-2/TM6B) stocks were incubated at $28^{\circ} \mathrm{C}$, and after 10 days of incubation were checked for the emerging pupae. Three virgin females (white-eyed), marked by whitish fat body, with black dot on their dorsal body, were collected and crossed with two RNAi driver male flies (red-eyed due to mini-white marker). The flies were initially looked regularly for checking health, and once the start laying eggs can be collected after ten days. Slides of dissected wings were made with controls as -

- Leon mutant females-W overexpressed by GAL 4 system.

- Leon mutant females-W/O GAL 4 overexpression.

\section{Selection of flies for studying wing phenotypes}

After 10 days of crossing, the progeny was collected and screened to eliminate all the male flies (white and red eyed) and female flies (white eyed with balancer phenotype like curved wings for cyo and short body with bristles for TM6B). The collected females for final wing dissection were straight-winged, red eyed, less bristles on the shoulder and longer body. Then, the collected flies were kept to freeze at $4^{\circ} \mathrm{C}$ for a day.

$$
\text { ms-gal4/ Y;RNAi / Cyo ; +/ + }
$$

\section{(Male)}

\section{$\mathbf{X}$}

+/ + ; +/+ ; Leon mutant 19-2/ TM6B

(Female)

Selected flies-

$\checkmark \quad$ ms-gal4 ; RNAi /+ ; Leon mutant 19-2/+

Rejected Flies:

ms-gal4 ; RNAi /+ ; + / TM6B

ms-gal4 ; + / Cyo ; Leon mutant 19-2 / +

ms-gal4 ; + / Cyo ; + / TM6B

\section{Wing dissection and microscopy}

The frozen flies were used to cut the wings from the proximal end, and the dissected wings were collected in an eppendorf with $100 \mu \mathrm{L}$ of PBST-Triton X buffer and left for mixing on a shaker for an hour. After though washing with PBST buffer, the wings were mounted on slides using 1:1 solution of Hoyer and Lactic acid (around 1-2 drops). The coverslip was fixed with acetone and later filmed under light microscope, and images were analyzed with the control images. The tissue specificity of the gene targeted by RNAi is checked by GFP tagging of the protein with GAL4 (GAL4-GFP-RNAi), which was later analyzed by fluorescence microscopy (Figures 3 and 4).

\section{Parameterization}

Each of these parameters is equally likely to occur, and thus given a score of 1 .These were used to calculate the severity of the effect, if seen any. The size of the wing hasn't been considered as a parameter with a score of one, because of the fact that the size modifications were not equally likely, and was observed for very few of the fly lines which showed effect.

$>$ Segmental distance between LCVs

$>$ Anterior Cross vein

$>$ Posterior Cross vein

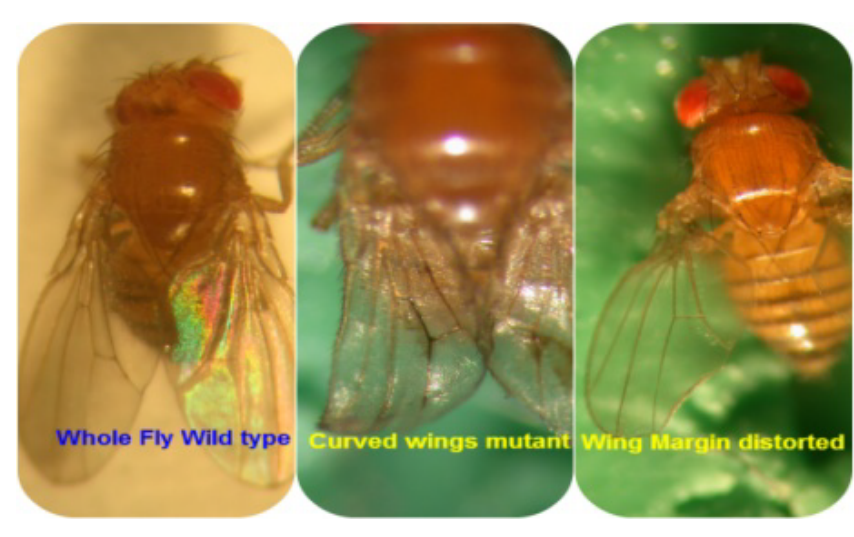

Figure 3: Whole Fly comparison of mutant and control for wing morphology.

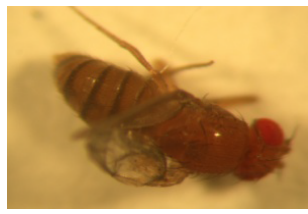

Rescued->

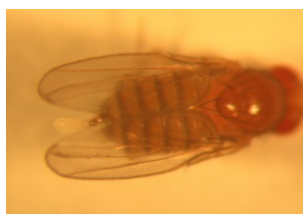

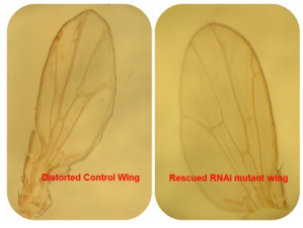

Score-6/6

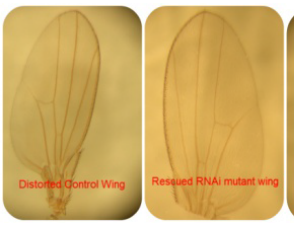

Score-3/6

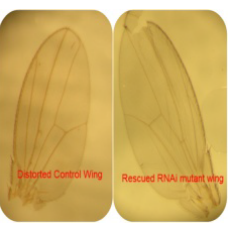

Score-1/6
Figure 4: Rescued whole fly and wing slides with scores of rescue.

$>$ Wing notching

$>$ Vein nodes at the proximal and distal ends

$>$ Bristles and serration to form lobe at L5.

\section{Scoring the effect}

Percentage of Effect $($ Rescue / Distortion $)=\frac{\text { No of parameters affected }}{\text { Total possible parameters to be affected }} \times 100$

\section{Results and Discussion}

Broadly the wing phenotype modifications can be classified into-

$>$ Rescue - Improved wing architecture in progeny vs. control.

Deteriorated (D) -degraded wing architecture in progeny vs. control.

$>$ No Effect $(\mathrm{N})$-wing architecture same as control.

\section{Rescue ${ }^{\circledR}$}

The rescue phenotype is an important analysis study in Drosphila genetics,considering the beneficial effects, that can be further extracted of it.However,there is a strict variation in the number of parameters rescued, or in other terms, the relative degree of development of wing blade in the co-expressed mutant in comparison to the control. A score of $6 / 6$ sets out an extreme rescue event, in which all the parameters considered to be expressed, are actually rescued. A 3/6 rescue symbolises $50 \%$ reswcue and a $1 / 6$ sets out the lower extreme of rescue phenotype, i.e. minimum parameter rescued. The images seen above show the effect on wing margin bristles is a rare effect seen, whereas segmental 
distance, acv and pcv are most distinctly effected or rescued parts. For a 3/6 score, acv, L4-L5 segmental distance and lobe formation at L5 is recued, and thus, taking into account three parameters. Similarly, the results for all the fly lines were computed (Figure 5).

The ability to resue the wing patterning features in Drosophila is seen to be mostly for a $50 \%$ rescue, i.e. a score of $3 / 6$. In general, the fly homeostasis allows a $50 \%$ rescue of wing phenotypes. Evolutionarily,this seems top be convinciong because of the possibility that the extreme rescue events (score of 5/6 or 6/6 ) might lead to cross talking of the basic intra-cellular signaling pathways, and thereby, negaqtively affecting fly vaibility. The least favorable rescue is observed to be $5 / 6$ or $83 \%$ rescue, meaning the rescue percent 50 , is an thershold in deciding teither the fly favors below 50\% rescue (considering fly system efficfiency). But an efficient fly system can actually favor very high degrees of rescue (score of $5 / 65$ or $6 / 6$ ). The Rescue percentage is also the differentially driven by the RNAi overexpression levels. The gradient of expression may also effect the percentage of rescue.

\section{Deterioration}

The deterioration of wing balde induced due to RNAi, is a very common effect observed with the severity of distortion varying with the fly linesw dependng on the fly system integrity and the RNAi overexpression levels. A 6/6 distortion shows complete loss of wing blade charecteristics features, and thus marks an extreme with a $1 / 6$ being the lower extreme with one parameter loss, generally being the acv/pcv or the segmental distance variation. A 3/6 scored fly line had distorted in terms of acv, L4-L5 segmental loss and the lobe at 15 loss with loss of terminal L5 vein at the distal end. This sytem was used in classifying the fly lines as per the distortion percentage, a possible answer to the fly machinery efficiency (Figure 6).
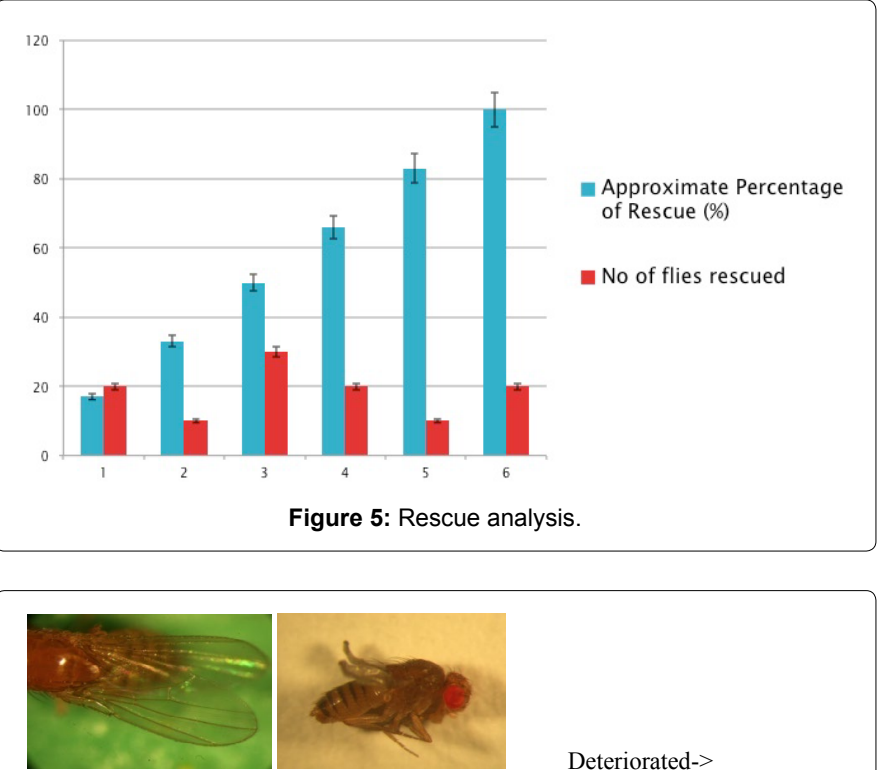

Deteriorated->

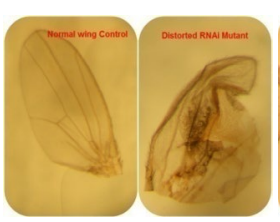

Score-6/6

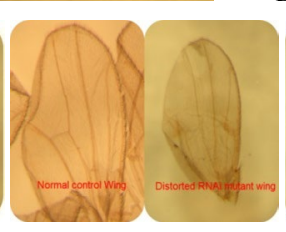

Score-3/6

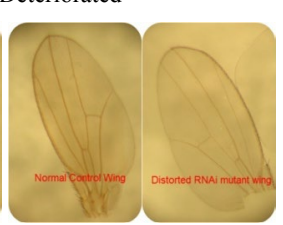

Score-1/6
Figure 6: Distorted Whole fly and wing slides with scores of deterioration.

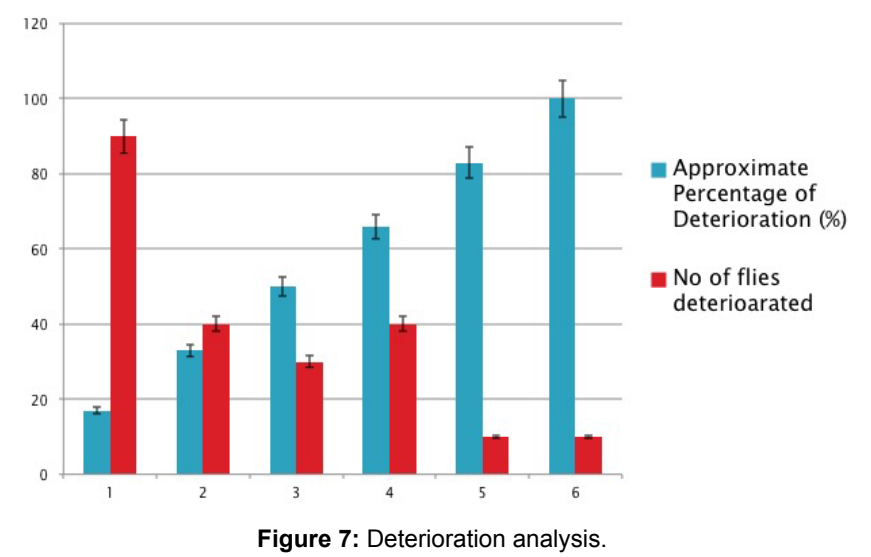

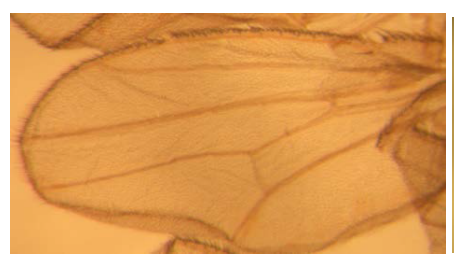

Control

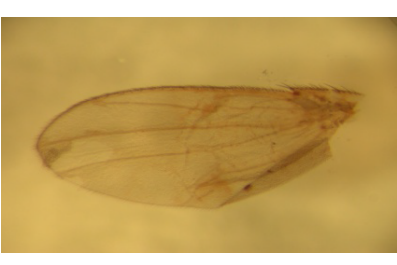

Mutant
Figure 8: Simultaneous rescue and distortion in the same fly line.

The deterioration phenoytpe is commonly seen for a single parameter loss, i.e score of $1 / 6$. The general loss being, loss of acv/pcv or segmental distance modifications. Considering the evolution significiance, the distortion percentage mostly lying at $15 \%$, also signifies the sensitivity of the fly machinery to the negative or deleterious effects of mutation on the physiology.The least favorable deterioration is for a $5 / 6(83 \%)$ or $6 / 6(100 \%)$ deterioration, confirming the earlier suggested possibility of the stircter sensitivity opf fly machinery to negative changes of the phsiology, thereby affecting homoestasis. This distortion possible might have arised out of the difference in RNAi overexpression in the fly lines, but mostly $15 \%$ distortion is what lies in the favorable range of fly homeostasis (Figure 7).

\section{Both rescued and deteriorated}

A very distinctive effect is the same co expressed fly wing exhibiting both rescue and deterioration phenotypes together. However, the degree of rescue or distortion is different and mostly the fly lines, which showed this dual effect, had deterioration score outweighing the rescue. The possible factor accounting for such a phenotypic expression roots to the sensitivity of the signaling pathways guiding the positioning of wing patterns. The signaling pathways when simultaneously perceive both rescue and distortion the fly machinery favors deterioration of the wing phenotypes, mostly inhibiting the wing vein proteins in such cases, in an effort to maintain homeostasis (Figure 8).

\section{Rescue ${ }^{\oplus}$-wing notching: Score-1/6}

Distorted (D)-acv completely lost, pcv apparently exists, L5 lost, venation distorted; Score- $4 / 6$

\section{RNAi gradient and effects correlation}

The varying intensity of RNAi overexpression helps us to cross check whether the RNAi is showing desired effect. For the severely expressed RNAi, cases with no effect theoretically should be minimum and some affect either rescue or distortion should dominate and that is marked in 
Citation: Satapathy S, Chien CT (2013) RNAi Induced Wing Modification in Leon Mutant Drosophila Females: Exploring the Tissue Specificity and Physiological Interference. Gene Technology 2: 104. doi: 10.4172/2329-6682.1000104

Page 5 of 6

the analysis results (Figure 9). In the severely expressed RNAi rescue, phenotypes are most commonly seen whereas it is negligibly less in mid and normally expressed RNAi. For mid and normally expressed ones, there is a significant fly line population showing no effect, which possibly is due to the non specificity of the genes targeted by RNAi, where such genes either show tissue specific expression in reproductive tissues or carcass, and are not linked to the wing development from imaginal disc (Table 1).

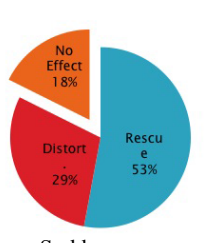

Sodden

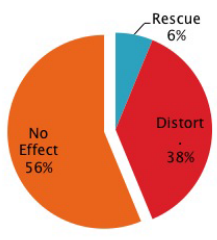

Mid

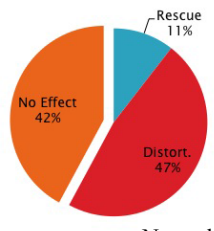

Normal

Figure 9: RNAi gradient with effect types.

\begin{tabular}{|c|c|c|c|c|c|c|c|c|c|c|}
\hline SI. No. & \multicolumn{3}{|c|}{ Tube Label Targeted Gene } & Related gene \& function & \multicolumn{2}{|c|}{$\begin{array}{l}\text { Expression in adult } \\
\text { Tissue }\end{array}$} & \multicolumn{3}{|c|}{ Observed Phenotype } & $\begin{array}{l}\text { Physiological/Metabolic } \\
\text { Function }\end{array}$ \\
\hline 1 & \multicolumn{3}{|c|}{$\begin{array}{l}\text { 17260R-1/ CG17260 } \\
\text { T6 }\end{array}$} & $\begin{array}{l}\text { C G } 17259 \text { a m in o a cyl } \\
\text { t-RNA synthetase class II) }\end{array}$ & \multicolumn{2}{|c|}{$\begin{array}{l}\text { Testis and male } \\
\text { reproductive tissue }\end{array}$} & \multicolumn{3}{|c|}{$\begin{array}{l}\text { Rescued-Proximal Wing vein and acv } \\
\text { restored }\end{array}$} & $\begin{array}{l}\text { Zinc ion binding, Protein features-RWD } \\
\text { Domain. }\end{array}$ \\
\hline 2 & \multicolumn{3}{|c|}{$\begin{array}{l}106192 / \text { CG5794 } \\
\text { CyO }\end{array}$} & $\begin{array}{l}\text { at1 (guanyl ribonucloetide } \\
\text { binding.) }\end{array}$ & \multicolumn{2}{|c|}{ Brain, Imaginal Disc } & \multicolumn{3}{|c|}{$\begin{array}{l}\text { Rescued-wing notching lost } \\
\text { Distorted- } \\
\text { acv, pcv and wing vein lost }\end{array}$} & $\begin{array}{l}\text { Ubiquitin thioesterase activity, } \\
\text { regulation of gene silencing, protein } \\
\text { ubiquitination. }\end{array}$ \\
\hline 3 & \multicolumn{3}{|c|}{ 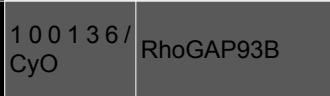 } & $\begin{array}{|lr|}\text { CG7056 } & \text { (specific DNA } \\
\text { binding } & \text { Transcription } \\
\text { Factor) } & \\
\end{array}$ & \multicolumn{2}{|c|}{$\begin{array}{l}\text { Brain and Thoracic } \\
\text { Abdominal ganglion }\end{array}$} & \multicolumn{3}{|c|}{$\begin{array}{l}\text { Distorted-acv,L3-L4 distance, } \\
\text { proximal vein }\end{array}$} & $\begin{array}{l}\text { Rho-GTPase activity, axon guidance } \\
\text { activity, Myth4 domain in proteins. }\end{array}$ \\
\hline 4 & 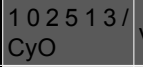 & \multicolumn{2}{|l|}{ vito } & $\begin{array}{ll}\text { Scny } & \text { (Ubiquitin } \\
\text { thioesterase) }\end{array}$ & \multicolumn{2}{|c|}{$\begin{array}{l}\text { Female reproductive } \\
\text { parts }\end{array}$} & \multicolumn{3}{|c|}{ Distorted-pcv } & $\begin{array}{l}\text { Positive regulation of cell growth, acts } \\
\text { as a nucleoprotein }\end{array}$ \\
\hline 5 & \multicolumn{3}{|c|}{$\begin{array}{l}100708 / \mathrm{Src} 42 \mathrm{~A} \\
\text { CyO }\end{array}$} & mle (chromatin binding) & \multicolumn{2}{|c|}{ CNS, Imaginal DISC } & \multicolumn{3}{|c|}{$\begin{array}{l}\text { Rescued-acv,pcv,L4,L5,L3-L4 distance } \\
\text { widened }\end{array}$} & $\begin{array}{l}\text { Protein tyrosine kinase activity, } \\
\text { biogenesis regulator, } \\
\text { compartmentalization }\end{array}$ \\
\hline 6 & \multicolumn{3}{|c|}{$\begin{array}{ll}38998 & / \\
\text { CyO Gint3 }\end{array}$} & $\begin{array}{l}\text { Sp } 2637 \text { (asparagine } \\
\text { activity) }\end{array}$ & \multicolumn{2}{|c|}{$\begin{array}{l}\text { E y e, Th o r a c i c } \\
\text { abdominal ganglion }\end{array}$} & \multicolumn{3}{|c|}{ Rescued-acv,pcv,vein architecture } & $\begin{array}{l}\text { Protein binding,PUB domain,PUG } \\
\text { domain, UBX domain. }\end{array}$ \\
\hline 7 & \multicolumn{3}{|c|}{$\begin{array}{l}108832 / \\
\text { CyO }\end{array}$} & $\begin{array}{l}\text { CG9330(ATPase activity, } \\
\text { transporter) }\end{array}$ & \multicolumn{2}{|l|}{ Ovary } & \multicolumn{3}{|c|}{$\begin{array}{l}\text { Rescued-acv,proximal wing veins of } L 3 \\
\& L 4\end{array}$} & $\begin{array}{l}\text { Histone lysine } \mathrm{N} \text {-methyl trasferase } \\
\text { activity,ssRNA binding activity }\end{array}$ \\
\hline 8 & $\begin{array}{l}101684 / \\
\text { CyO }\end{array}$ & ru, rh & & & Brain,E & ye, head & $\begin{array}{l}\text { Distorte } \\
\text { end }\end{array}$ & $d-L 2-L 3$ narrowed at prox & imal & Serine-type peptidase activity \\
\hline 9 & $\begin{array}{l}105883 / \\
\text { CyO }\end{array}$ & Rbp1 & & $\begin{array}{l}\text { Tim9a (P-P bond } \\
\text { hydrolysis driven protein) }\end{array}$ & Brain & & Distorte & d-Notching,acv lost, vein disto & orted & $\begin{array}{l}\text { Nucleotide binding, nucleic acid } \\
\text { binding,RNA splicing }\end{array}$ \\
\hline 10 & $\begin{array}{l}23263 \\
\mathrm{CyO}\end{array}$ & DN-R & b14 & & & & $\begin{array}{l}\text { Distorte } \\
\text { widene }\end{array}$ & lost,L3-L4 & nent & \\
\hline 11 & $\begin{array}{l}9379 R-21 \\
\text { T6 }\end{array}$ & By & & mura (zinc ion binding) & $\begin{array}{l}\text { Crop } \\
\text { gland }\end{array}$ & and salivary & Distort & d-Wing venation & & Actin binding, wing morphogenesis \\
\hline 12 & $\begin{array}{l}100809 / \\
\text { CyO }\end{array}$ & Vap-3 & & $\begin{array}{l}\text { Lva (actin/microtubule } \\
\text { binding) }\end{array}$ & Brain,E & ye,Heart & Distorte & d-pcv shifted,L4-L5 widened & & $\begin{array}{l}\text { Structural molecule activity, innate } \\
\text { immune response }\end{array}$ \\
\hline 13 & $\begin{array}{l}101669 / \\
\text { CyO }\end{array}$ & Hsp2 & & $\begin{array}{l}\text { Hsp 23(hypoxia, cold } \\
\text { acclimation) }\end{array}$ & $\begin{array}{l}\mathrm{M} \text { a I } \\
\text { tubules }\end{array}$ & $\begin{array}{l}\mathrm{h} \text { a g i a } \mathrm{n} \\
\text { Ovary }\end{array}$ & Distorte & d-L3-L54 widened & & Protein binding, defense response \\
\hline 14 & 11152/Cy & & scny & Vito (cell growth regu & ulator) & Brain, eye, $h$ & iead, & Distorted-L4-L5 widened & & $\mathrm{n}$ thioesterase activity \\
\hline 15 & $105534 / C$ & & Rabex-5 & $\begin{array}{l}\text { Scf(topoisomer } \\
\text { activity) }\end{array}$ & rase & Salivary glan & & Distorted-L4-L5 narrowed & & aginal disc development \\
\hline 16 & $5562 R-3 / C$ & CyO & $\mathrm{gbb}$ & $\begin{array}{l}\text { elF6 (trans } \\
\text { elongation factor) }\end{array}$ & slation & $\begin{array}{l}\text { Salivary } \\
\text { male acc } \\
\text { gland }\end{array}$ & $\begin{array}{l}\text { gland, } \\
\text { sessory }\end{array}$ & $\begin{array}{l}\text { Rescued-acv, pcv, wing } \\
\text { vein restored }\end{array}$ & & $\begin{array}{l}\text { ansformation growth factor beta receptor } \\
\text { Iding, neurotransmitter regulator,NMJs } \\
\text { wth }\end{array}$ \\
\hline 17 & $105946 / C$ & & $e(y) 3$ & $\begin{array}{l}\text { MKP4 } \\
\text { activity) }\end{array}$ & hatase & Ovary, Eye & & $\begin{array}{l}\text { Distorted-L5, L } 4-L 5 \\
\text { widened }\end{array}$ & & $\begin{array}{l}\text { Iromatin binding, genesilencing, } \\
\text { aginal disc development }\end{array}$ \\
\hline 18 & $108814 / C$ & & TNF (egr) & CG2269 & & Eye, brain, h & eart & Distorted-acv,pcv,L5 & & otein binding,innate immunity \\
\hline 19 & $110618 / \mathrm{C}$ & & MRG15 & CG4338 & & Eye, brain, $\mathrm{O}$ & Dvary & Distorted-L4-L5 widened & & $\begin{array}{l}\text { thylated histone binding, chromatin } \\
\text { encing }\end{array}$ \\
\hline 20 & $6637 \mathrm{R}-2 / \mathrm{C}$ & CyO & Isn, Vps22 & $\begin{array}{l}\text { Eby } \\
\text { development) }\end{array}$ & rmatid & $\begin{array}{l}\text { Head, ovary } \\
\text { Brain }\end{array}$ & y, eye & Distorted-acv,pcv,veins & Apc & optosis \&notch signalling regulator \\
\hline 21 & $3998 \mathrm{R}-1 / \mathrm{C}$ & CyO & zf30C & $\begin{array}{l}\text { Taf11 (transcription } \\
\text { binding) }\end{array}$ & factor & $\begin{array}{l}\text { Brain, } \quad \text { Tr } \\
\text { abdominal ga }\end{array}$ & $\begin{array}{l}\text { horacic } \\
\text { anglion }\end{array}$ & Rescued-acv & & $\begin{array}{l}\text { uron development, } \mathrm{ZINC} \text { finger } \mathrm{C} 2 \mathrm{H} 2 \\
\text { main }\end{array}$ \\
\hline 22 & 51977/T6 & & fing & CG10589 & & $\begin{array}{l}\text { Thoracic abd } \\
\text { ganglion }\end{array}$ & lominal & $\begin{array}{l}\text { Distorted-pcv, L4-L5 } \\
\text { widened }\end{array}$ & Sin & gle organism development,biogenesis \\
\hline 23 & 10079R-1 & & EGFR & & & & & Distorted-L4-L5 widened & & \\
\hline
\end{tabular}

The database of the fly lines showing effect has been tabulated to compare and analyze the possible.

Table 1: RNAi -Leon Co expressed mutant and physiological interference. 
Citation: Satapathy S, Chien CT (2013) RNAi Induced Wing Modification in Leon Mutant Drosophila Females: Exploring the Tissue Specificity and Physiological Interference. Gene Technology 2: 104. doi: 10.4172/2329-6682.1000104

Page 6 of 6

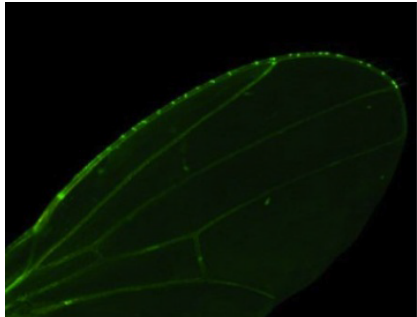

Wing Blade

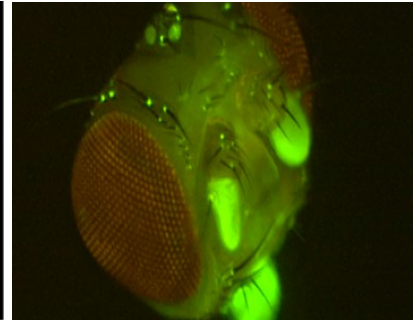

$\mathrm{Head} / \mathrm{Brain}$

Figure 10: Mostly RNAi showing effects are localized in wing disc, head or brain.

\section{Organ/Tissue localization}

Upon analysis, the most common tissue specific expression is seen in wing disc and brain or head. The expression was confirmed from the fly base data of fly anatomy of expression at adult stage. The GFP tagged fluorescent expression of these genes targeted showed the most RNAi lines, showing effect to be either expressed in brain and head. The expression in ovary, testis, fat body, salivary gland and thoracic abdominal ganglion were tissues which show relatively less expression in cases of fly showing either rescue or distortion effects. Mostly flies showing a distortion effect were involved in neurological functions and in development of sensory organs (Figure 10).

\section{Conclusion}

In general, rescue and deterioration phenotypes were seen in flies where genes targeted by RNAi are expressed at higher percentage, specifically in wing tissues or the imaginal disc (coding for wing development). Most common tissue specific expression in adult fly with change in wing patter is observed in brain, head, imaginal Disc, thoracic abdominal ganglion and eye. The RNAi gradient of over expression also influenced the phenotypic effect.

- Severely overexpressed RNAi $\rightarrow$ Predominantly Rescue phenotype.

- Mid overexpressed RNAi $\rightarrow$ Mostly No effect with few cases of distortion.

- Normally Overexpressed RNAi $\rightarrow$ Predominantly Distortion

The further analysis of these phenotypic changes can give an idea of the intracellular signaling pathways specifically targeted by these RNAi fly lines co expressed with Leon mutant. Information on position and morphogens are of prime importance in studying developmental biology. In Drosophila system, there are several diffusible proteins along the anterior-posterior compartments, leading to the nested expression of certain specific genes, which regulate the wing venation and cell positioning. Still even after 15 years of intense research about wing patterning, the scaled presence of morphogens and fate decision of wing disc cells in response to the five basic intracellular signaling pathways still remains not completely understood. However, the stereotyped use of wing pattern analysis in understanding the possible effect on physiology and developmental sequence still holds to be of significance.

\section{Acknowledgments}

I would like to thank Man Wen Chen, Li-Shin and Pei-Fung, for their support and help in completion of this project. Taiwan International Graduate Program (TIGP)-International Internship Program 2013 and Institute of Molecular Biology (IMB), Academia Sinica, Taiwan, have funded this project.

\section{References}

1. Acheson SK, Stein RM, Swartzwelder HS (1998) Impairment of semantic and figural memory by acute ethanol: Age-dependent effects. Alcohol Clin Exp Res 22: $1437-1442$.

2. UMLS Quick Start Guide (1994) Diagnostic and Statistical Manual of Mental Disorders. Am Psychiatry Assoc, (4th Edn), Washington DC: APA, USA.

3. Ashburner M (1998) Speculations on the subject of alcohol dehydrogenase and its properties in Drosophila and other flies. Bioessays 20: 949-954.

4. Bangi E, Wharton K (2006) Dual function of the Drosophila Alk1/Alk2 ortholog Saxophone shapes the Bmp activity gradient in the wing imaginal disc. Development 133: 3295-3303.

5. Becker HC, Diaz-Granados JL, Randall CL (1996) Teratogenic actions of ethanol in the mouse: A minireview. Pharmacol Biochem Behav 55: 501-513.

6. Campbell G, Tomlinson A (1999) Transducing the Dpp morphogen gradient in the wing of Drosophila: Regulation of Dpp targets by brinker. Cell 96: 553-562.

7. Blair SS (2007) Wing vein patterning in Drosophila and the analysis of intercellular signaling. Annu Rev Cell Dev Biol 23: 293-319.

8. Barclay DC, Hallbergson AF, Montague JR, Mudd LM (2005) Reversal of ethanol toxicity in embryonic neurons with growth factors and estrogen. Brain Res Bull 67: 459-465.

9. Gilchrist AS, Partridge $L$ (2001) The contrasting genetic architecture of wing size and shape in Drosophila melanogaster. Heredity (Edinb) 86: 144-152.

10. Garcia-Bellido A, Merriam JR (1971) Parameters of the wing imaginal disc development of Drosophila melanogaster. Dev Biol 24: 61-87.

11. Blair SS (1995) Compartments and appendage development in Drosophila Bioessays 17: 299-309.

12. Blair SS, Palka J (1985) Axon guidance in the wing of Drosophila. Trend Nuerosci 8: 284-288.

13. Bryant PJ (1970) Cell lineage relationships in the imaginal wing disc of Drosophila melanogaster. Dev Biol 22: 389-411.

14. Brunner D, Dücker K, Oellers N, Hafen E, Scholz H, et al. (1994) The ETS domain protein pointed-P2 is a target of MAP kinase in the sevenless signal transduction pathway. Nature 370: 386-389.

15. Babor TF, Berglas S, Mendelson JH, Ellingboe J, Miller K (1983) Alcohol, affect and the disinhibition of verbal behavior. Psychopharmacology (Berl) 80: 53-60.

16. De Celis JF, Diaz-Benjumea FJ (2003) Developmental basis for vein pattern variations in insect wings. Int J Dev Biol 47: 653-663.

17. Duffy JB (2002) GAL4 system in Drosophila: A fly geneticist's Swiss army knife. Genesis 34: 1-15.

18. Bier E (2005) Drosophila, the golden bug, emerges as a tool for human genetics. Nat Rev Genet 6: 9-23.

19. Bitner-Mathé BC, Klaczko LB (1999) Heritability, phenotypic and genetic correlations of size and shape of Drosophila mediopunctata wings. Heredity (Edinb) 83: 688-696.

20. Weber KE (1990) Selection on wing allometry in Drosophila melanogaster Genetics 126: 975-989.

21. Barbancho M, Sánchez-Cañete FJ, Dorado G, Pineda M (1987) Relation between tolerance to ethanol and alcohol dehydrogenase (ADH) activity in Drosophila melanogaster: Selection, genotype and sex effects. Heredity (Edinb) 58: 443-450. 